\title{
Paired Box Protein Pax-5
}

National Cancer Institute

\section{Source}

National Cancer Institute. Paired Box Protein Pax-5. NCI Thesaurus. Code C30124.

Paired box protein Pax-5 (391 aa, $42 \mathrm{kDa}$ ) is encoded by the human PAX5 gene. This protein plays a role in B-cell differentiation, neural development, spermatogenesis and gene transcription. 